\section{Containerized Muskmelon Transplants: Cell Volume Effects on Pretransplant Development and Subsequent Yield}

\author{
Elizabeth T. Maynard \\ Department of Horticulture, Purdue University, Northwest Commercial \\ Horticulture Program, Hammond, IN 46323
}

Charles S. Vavrina

Southwest Florida Research and Education Center, University of Florida, P.O. Drawer 5127, Immokalee, FL 33934

\author{
W. Dennis Scott ${ }^{1}$ \\ Department of Horticulture, Purdue University, Southwest Purdue Agriculture \\ Program, R.R. 6, Box 139A, Vincennes, IN 47591
}

Additional index words. cantaloupe, Cucumis melo

\begin{abstract}
Muskmelon (Cucumis melo L. cvs. Superstar and Mission) transplants were grown in cellular seedling trays of polystyrene or styrofoam, with individual cells ranging in volume from 7 to $100 \mathrm{~cm}^{3}$, transplanted to the field, and grown to maturity in Florida and Indiana during the 1993 and 1994 growing seasons. Seedling leaf area, shoot and root weights before transplanting, and shoot dry weight 20 days after transplanting increased linearly with increasing cell volume in Florida. Thirty days after transplanting, vine length showed significant linear and quadratic trends with respect to cell volume in Indiana. In Florida, early and total yields increased linearly as transplant cell volume increased for 'Mission' in both years and for 'Superstar' in 1994. In Indiana, early yields increased linearly as transplant cell volume increased for 'Mission' in 1994 and for 'Superstar' in both years, but cell volume did not consistently affect total yield. Transplant tray effects on early and total yield unrelated to linear or quadratic effects of cell volume occurred in both locations, but these effects were not consistent.
\end{abstract}

Cost-effective use of greenhouse space for transplant production often demands efficiency with respect to the number of plants per unit area. Transplant production has been estimated to account for $14 \%$ of total growing costs for muskmelon (Weimar and Taber, 1987). Pressures to reduce costs and maximize efficiency of transplant production have prompted interest in growing muskmelon transplants in smaller cell volumes than are used traditionally. Doubling the number of muskmelon seedlings in a greenhouse could reduce the per-plant cost by $35 \%$ to $40 \%$, based on fixed and variable costs estimated for transplant production in Florida (Zimet and Vavrina, 1995).

Studies on other vegetable crops suggest that if the transplant cell size is too small, reductions in total or early yield or product size may occur. Marsh and Paul (1988) reported that cabbage (Brassica oleracea L. Capitata Group) produced heavier heads when grown in $80-\mathrm{cm}^{3}$ cells than in $7-\mathrm{cm}^{3}$ cells.

Received for publication 14 July 1995. Accepted for publication 7 Nov. 1995. Journal paper no. 14723, Purdue Agricultural Expt. Station. The cost of publishing this paper was defrayed in part by the payment of page charges. Under postal regulations, this paper therefore must be hereby marked advertisement solely to indicate this fact.

${ }^{1}$ Current address: FMC Corp., Agricultural Chemical Group, 27 Tremont Dr., College Place, WA 99324.

${ }^{\mathrm{z}} \mathrm{X}$ indicates container was used at this location and year. (in tonnes per hectare) when grown in $40-\mathrm{cm}^{3}$ cells than in $19-\mathrm{cm}^{3}$ cells, while yield of 'Crimson Sweet' was not affected (Hall, 1989). In another study, 'Charleston Gray' watermelons grown in cells ranging from 19 to $66 \mathrm{~cm}^{3}$ did not differ in yield (Vavrina et al., 1993).

In Florida and Indiana, muskmelons are grown primarily for local and regional markets. Cultivars commonly grown in Indiana are large-fruited, deeply ridged, eastern types. In Florida, smaller, heavily netted and nonridged western types are preferred. Traditionally, Indiana growers produced transplants in 10-cm "dirt bands" filled with compost. Many growers have switched all or part of transplant production to cellular transplant trays. Polystyrene trays with a volume of 50 to $70 \mathrm{~cm}^{3}$, corresponding to 72 or 50 cells, are commonly used (W.D.S., personal observation). In Florida, transplant production is almost exclusively in styrofoam trays, most commonly with a volume of $36 \mathrm{~cm}^{3}$, corresponding to a 128-cell styrofoam flat (C.S.V., personal observation).

We determined whether transplant containercell volume influences muskmelon yield, earliness, or fruit size. Trays were selected to include types commonly used in Indiana and Florida, as well as trays of similar design but with smaller cells than are used typically.

\section{Materials and Methods}

Muskmelon transplants were grown in commercially available trays of seven cell sizes in Indiana and six cell sizes in Florida, providing cell volumes ranging from 7 to $100 \mathrm{~cm}^{3}$ (Table $1)$. The cells differed in shape and material as well as size: styrofoam trays had inverted square pyramidal cells (Speedling, Sun City, Fla.); polystyrene trays with $26-$ or $50-\mathrm{cm}^{3}$ cells were square in cross-section and slightly tapered (TLC Polyform, Plymouth, Minn.); and polystyrene trays with $25-, 70-$, or $100-$ $\mathrm{cm}^{3}$ cells had slightly tapered cylindrical cells (Growing Systems, Milwaukee). A western shipping-type muskmelon, 'Mission', and a deeply ridged eastern type, 'Superstar', were seeded in peat-based growing medium (Metro Mix 220 or Terra-Lite 300; Grace Sierra, Milpitas, Calif.) on 1 Sept. 1993 and 29 Aug. 1994 in Florida and 27 Apr. 1993 and 20 Apr. 1994 in Indiana. Seedlings were watered as needed by hand from above and fertilized a total of three times with a soluble fertilizer containing $\mathrm{N}$ at $250 \mathrm{mg} \cdot \mathrm{liter}^{-1}$ from $20 \mathrm{~N}-$

Table 1. Transplant container characteristics and location and year used.

\begin{tabular}{|c|c|c|c|c|c|c|c|c|}
\hline \multirow[b]{3}{*}{ Material } & \multicolumn{4}{|c|}{ Cell } & \multirow{3}{*}{$\begin{array}{c}\text { Surface area/ } \\
\text { plant }\left(\mathrm{cm}^{2}\right)\end{array}$} & \multirow{3}{*}{$\begin{array}{c}\text { Florida } \\
1993 \text { and } 1994\end{array}$} & \multirow{2}{*}{\multicolumn{2}{|c|}{ Indiana }} \\
\hline & \multirow{2}{*}{$\begin{array}{c}\text { Count } \\
\text { (no.) }\end{array}$} & \multirow{2}{*}{$\begin{array}{c}\text { Vol } \\
\left(\mathrm{cm}^{3}\right)\end{array}$} & \multirow{2}{*}{$\begin{array}{l}\text { Depth } \\
(\mathrm{cm})\end{array}$} & \multirow{2}{*}{$\begin{array}{c}\text { Cross- } \\
\text { sectional } \\
\text { shape }\end{array}$} & & & & \\
\hline & & & & & & & 1993 & 1994 \\
\hline \multirow[t]{3}{*}{ Styrofoam } & 338 & 7 & 4.8 & Square & 6.4 & $\mathrm{X}^{\mathrm{z}}$ & $X$ & $\mathrm{X}$ \\
\hline & 200 & 22 & 8.2 & Square & 10.9 & $X$ & $X$ & $X$ \\
\hline & 128 & 36 & 6.5 & Square & 17.0 & $X$ & $X$ & $X$ \\
\hline \multirow{5}{*}{ Polystyrene } & 128 & 26 & 5.0 & Square & 10.3 & & & $X$ \\
\hline & 96 & 25 & 3.8 & Round & 16.1 & $X$ & $X$ & \\
\hline & 72 & 50 & 6.0 & Square & 19.8 & $\mathrm{X}$ & $\mathrm{X}$ & $X$ \\
\hline & 51 & 70 & 5.5 & Round & 30.4 & $\mathrm{X}$ & $X$ & $\mathrm{X}$ \\
\hline & 33 & 100 & 6.5 & Round & 47.0 & & $X$ & $X$ \\
\hline
\end{tabular}


8.6P-16.6K (Nutrileaf; Miller Chemical Co., Hanover, $\mathrm{Pa}$.) or N at $580 \mathrm{mg} \cdot \mathrm{liter}^{-1}$ from $30 \mathrm{~N}-$ 13P-12K (Stern's Miracle-Gro, Port Washington, N.Y.) in Florida and Indiana, respectively. Seedlings were transplanted to field plots by hand on 30 Sept. 1993 and 20 Sept. 1994 in Florida and 27 May 1993 and 18 May 1994 in Indiana. Transplant tray treatments and cultivars were arranged in a randomized complete-block design in the field, with six replications in Florida and four replications in Indiana. Single-row experimental plots were $10 \times 1.8 \mathrm{~m}$ with plants $0.9 \mathrm{~m}$ apart in Florida and $12.2(1993)$ or $9.1(1994) \times 1.8 \mathrm{~m}$ with plants $1.2 \mathrm{~m}$ apart in Indiana. Plants that died after transplanting were replaced with transplants from the same tray treatment within 2 weeks. Plants were grown using cooperative extension-approved cultural and pest management practices for each production area, including white plastic mulch and raised beds in Florida and black plastic mulch in Indiana (Foster et al., 1993; Hochmuth, 1988). In Florida, $8.0 \mathrm{~N}-8.3 \mathrm{P}-5.0 \mathrm{~K}$ was applied before bed formation to supply 36 and $50 \mathrm{~kg} \mathrm{~N} / \mathrm{ha}$ in 1993 and 1994, respectively, followed by $19.0 \mathrm{~N}-0 \mathrm{P}-24.9 \mathrm{~K} \approx 40$ days later to supply 45 and $36 \mathrm{~kg} \mathrm{~N} /$ ha in 1993 and 1994, respectively. In Indiana, $54 \mathrm{~kg} \mathrm{~N}, 24 \mathrm{~kg} \mathrm{P}$, and $89 \mathrm{~kg} \mathrm{~K} / \mathrm{ha}$ were broadcast and incorporated, and $80 \mathrm{~kg} \mathrm{~N} /$ ha was applied beneath plastic at the time plastic was laid. In Florida, beds were treated with methyl bromide at $250 \mathrm{~kg} \cdot \mathrm{ha}^{-1}$. No fumigant or herbicide was used in Indiana; weeds were controlled by cultivation and hand-weeding. Irrigation was provided as needed from subsurface seepage in Florida and from drip tape in Indiana.

Before transplanting, leaf area and shoot and root dry weights of five plants per tray treatment and cultivar were measured in Florida, and leaf area of 10 plants from each of five tray treatments per cultivar was measured in Indiana in 1994. Vine growth was measured 20 to 30 days after transplanting (DAT). In Florida, one plant per plot was cut at the soil surface, oven-dried, and weighed. In Indiana, lengths of the main stem and three primary branches of three plants per plot were averaged to give the mean length of a single vine per plant. Ripe fruit was harvested from all plants in each plot on 30 Nov. and 3, 7, 10, and 13 Dec. 1993 and 10, 14, 17, 19, 21, 23, 26, and 29 Nov. 1994 in Florida and on 7, 21, 23, 26, 28, and 30 July and 2 Aug. 1993 and 11, 14, 18, 21, 25, and 28 July and 1 Aug. 1994 in Indiana. Number and weight of fruit were determined. In 1994, split melons were counted but not weighed in Florida.

Data were analyzed separately for each year and location because of variations in transplant tray size in the various trials. Seedling data were analyzed by regressing means of each treatment (tray $\times$ cultivar) against cell volume and testing for main effect of cultivar, linear and quadratic effects of cell volume, and their interactions. Vine growth and yield data were tested using analyses of variance to evaluate main effects of cultivar, cell volume, and their interaction. Effects of cell volume were evaluated using orthogonal polynomials: lin- ear and quadratic trends were evaluated for significance, and higher-order polynomials were pooled to test for residual effects of transplant trays not related to linear or quadratic effects of cell volume. Coefficients for the orthogonal contrasts were constructed to take into account the unequal spacing of cell volumes, and orthogonality was checked by verifying that partial and sequential sums of squares were the same. Cultivar $\times$ tray treatment interactions are presented in tables only when significant. Early yields were defined to represent $20 \%$ to $40 \%$ of total yield averaged across cell size treatments as follows: in Florida, fruit picked the first two (1993) or three (1994) harvests for 'Superstar' and the first three (1993) or four (1994) harvests for 'Mission' and in Indiana fruit picked the first four (1993) or two (1994) harvests for 'Superstar' and the first five (1994) harvests for 'Mission'. Early yields of 'Mission' in Indiana in 1993 were not determined because the cultivar was harvested on only two dates before it succumbed to disease. Because early yields comprised different harvests for the two cultivars, analyses of early yields were performed separately for each cultivar. All statistical analyses were performed using JMP version 2 (SAS Institute, Cary, N.C.)

Table 2. Effect of transplant container cell volume on growth of 'Mission' and 'Superstar' muskmelon plants before and after transplanting in Florida and Indiana. ${ }^{\mathrm{z}}$

\begin{tabular}{|c|c|c|c|c|c|c|c|}
\hline \multirow[b]{4}{*}{ Main effect } & \multicolumn{5}{|c|}{ Before transplanting } & \multicolumn{2}{|c|}{ After transplanting } \\
\hline & \multirow{2}{*}{\multicolumn{2}{|c|}{$\begin{array}{c}\text { Leaf area } \\
\left(\mathrm{cm}^{2}\right)\end{array}$}} & \multicolumn{3}{|c|}{ Florida } & \multirow{3}{*}{$\begin{array}{l}\text { Shoot dry } \\
\text { wt (g) } \\
\text { Florida }\end{array}$} & \multirow{3}{*}{$\begin{array}{c}\text { Vine } \\
\text { length }(\mathrm{cm}) \\
\text { Indiana } \\
\end{array}$} \\
\hline & & & \multirow{2}{*}{$\begin{array}{l}\text { Shoot dry } \\
\text { wt (mg) }\end{array}$} & \multirow{2}{*}{$\begin{array}{r}\text { Root dry } \\
\text { wt (mg) }\end{array}$} & \multirow{2}{*}{$\begin{array}{l}\text { Root : shoot } \\
\text { ratio }\end{array}$} & & \\
\hline & Florida & Indiana & & & & & \\
\hline & & & 1993 & & & & \\
\hline \multicolumn{8}{|c|}{ Cell volume $\left(\mathrm{cm}^{3}\right)$} \\
\hline 7 & 24.7 & $---y$ & 148 & 39 & 0.27 & 14.0 & 35.1 \\
\hline 22 & 42.2 & --- & 265 & 76 & 0.29 & 19.5 & 46.2 \\
\hline 25 & 44.0 & --- & 291 & 86 & 0.30 & 27.8 & 52.7 \\
\hline 36 & 50.7 & --- & 334 & 84 & 0.26 & 27.3 & 58.6 \\
\hline 50 & 48.7 & --- & 322 & 88 & 0.28 & 28.1 & 67.6 \\
\hline 70 & 68.9 & --- & 460 & 129 & 0.28 & 34.0 & 67.3 \\
\hline 100 & --- & --- & --- & --- & --- & -- & 80.1 \\
\hline \multicolumn{8}{|l|}{ Cultivar } \\
\hline Mission & 45.4 & --- & 316 & 81 & 0.26 & 24.9 & 51.7 \\
\hline Superstar & 47.7 & --- & 291 & 86 & 0.30 & 25.3 & 64.7 \\
\hline \multicolumn{8}{|c|}{ ANOVA summary ${ }^{\mathrm{x}}$} \\
\hline Cultivar & NS & --- & NS & NS & $*$ & NS & $* * *$ \\
\hline Cell volume & $\mathrm{L}^{* * * *}$ & --- & $\mathrm{L}^{* * * *}$ & $\mathrm{~L}^{* * * *}$ & NS & $\mathrm{L}^{* * * *}$ & $\mathrm{~L}^{* * * *}, \mathrm{Q}^{*}$ \\
\hline \multicolumn{8}{|c|}{1994} \\
\hline \multicolumn{8}{|c|}{ Cell volume $\left(\mathrm{cm}^{3}\right)$} \\
\hline 7 & 29.3 & 8.4 & 135 & 38 & 0.28 & 8.6 & 71.3 \\
\hline 22 & 49.1 & 18.1 & 236 & 71 & 0.31 & 13.4 & 83.6 \\
\hline $25^{\mathrm{w}}$ & 44.9 & 34.8 & 239 & 93 & 0.41 & 14.4 & 82.5 \\
\hline 36 & 62.3 & 36.2 & 281 & 79 & 0.28 & 17.6 & 97.2 \\
\hline 50 & 64.0 & --- & 321 & 104 & 0.33 & 16.6 & 93.8 \\
\hline 70 & 84.3 & 57.2 & 464 & 129 & 0.29 & 26.3 & 101.5 \\
\hline 100 & --- & --- & --- & --- & --- & --- & 102.4 \\
\hline \multicolumn{8}{|l|}{ Cultivar } \\
\hline Mission & 57.3 & 29.9 & 291 & 83 & 0.29 & 16.6 & 81.2 \\
\hline Superstar & 54.0 & 32.0 & 267 & 89 & 0.34 & 15.8 & 99.5 \\
\hline \multicolumn{8}{|c|}{ ANOVA summary ${ }^{\mathrm{x}}$} \\
\hline Cultivar & NS & NS & NS & NS & NS & NS & $* * *$ \\
\hline Cell volume & $\mathrm{L}^{* * * *}$ & $\mathrm{~L}^{* * * *}$ & $\mathrm{~L}^{* * * *}$ & $\mathrm{~L}^{* * * *}$ & NS & $\mathrm{L}^{* * *}$ & $\mathrm{~L}^{* * * *}, \mathrm{Q}^{* *}$ \\
\hline
\end{tabular}

${ }^{2}$ Measured 20 to 30 days after seeding or transplanting.

${ }^{y}$ No data.

${ }^{\mathrm{A}} \mathrm{ANOVA}=$ analysis of variance.

wCell volume was $26 \mathrm{~cm}^{3}$ in Indiana, 1994; otherwise $25 \mathrm{~cm}^{3}$.

Ns, ****,***Nonsignificant or significant at $P \leq 0.05,0.01$, or 0.0001 , respectively, for main effects of cultivar and linear $(\mathrm{L})$ or quadratic $(\mathrm{Q})$ effects of cell volume.
Seedling growth. Leaf area and shoot and root dry weights all increased linearly with cell volume (Table 2). Cell volume did not affect the root : shoot ratio. The two cultivars did not differ in leaf area or shoot or root dry weight, but in 1993, 'Mission' had a smaller

Vine length. The differences in vine length still were apparent in the field 30 DAT (Table 2). Shoot dry weight of plants increased linearly with increasing cell volume in Florida, but cultivars did not differ. In Indiana, vine length increased with cell volume up to 36 or $50 \mathrm{~cm}^{3}$ and then leveled off, as indicated by significant linear and quadratic effects. This result could reflect either a decreasing responsiveness to cell volume as volume increases or effects of cell characteristics, such as depth or shape, which are confounded with cell volume in this study. 'Superstar' vines were longer than 'Mission' vines.

Early yield. The number and weight of fruit harvested early increased with increasing cell volume in three of three trials for 'Mission' and three of four trials for 'Superstar' (Table 3 ). Effects of cell volume on the percentage of fruit harvested early were similar to those on root : shoot ratio than 'Superstar'. 
number of early fruit (data not shown). This finding is consistent with results in noncucurbit crops, where earliness was associated with increased cell size (Kemble et al., 1994; Weston, 1988; Weston and Zandstra, 1986). There was a significant residual effect of transplant tray after linear and quadratic responses to cell volume were accounted for in two of three trials for 'Mission' and one of four trials for 'Superstar'. However, these effects did not form a consistent pattern across locations and years. They may reflect differences in transplant establishment and growth related to cell shape, depth, or texture, factors that are known to influence tomato transplant growth (Liptay and Edwards, 1994).

Total yield. In Florida, the total number and weight of fruit produced per hectare increased with increasing cell volume in both years (Table 4). The linear relationship was stronger for 'Mission' than for 'Superstar', which resulted in a significant interaction between cultivar and the linear component of cell volume in most cases. In Indiana in 1993, the total number of fruit produced was not influenced by cell size, but the total weight of fruit increased linearly as cell volume increased (Table 4). In 1994, the cultivars differed in their response to cell size: 'Mission' yields decreased as cell volume increased, but 'Superstar' yield was not affected. 'Mission' produced more fruit than 'Superstar' in all trials, but total weight of fruit produced was the same for the two cultivars, except in Indiana in 1993 when 'Mission' was harvested only twice (Table 4).

These results are generally consistent with effects of cell size reported for other crops, including watermelons: effects on total yield are variable and depend, in part, on cultivar (Hall, 1989; Kemble et al., 1994; Vavrina et al., 1993; Weston, 1988; Weston and Zandstra, 1986). Cell volume effects on total yield tended to be more statistically significant in Florida than in Indiana (Table 4), which we expected based on more replications and the larger plot size in Florida in 1994. The difference in significance also may reflect a real difference in the importance of cell volume to yield in the two locations. In Indiana, weather at the normal time of transplanting is often too cool for optimum muskmelon growth. For example, nights dropped to <10C on three nights in 1993 and six nights in 1994 the first week after transplanting. These adverse conditions may have reduced the effects of cell volume in Indiana directly. In addition, replacement plants held for 1 week in the greenhouse experienced better growing conditions than plants surviving in the field. This difference could have resulted in confounding of cell size effects and date of planting effects since transplants from smaller cell sizes may have died more readily in the field (W.D.S., personal observation). In Florida, fall conditions are typically favorable for crop establishment, with average low and high temperatures between 18 and 30C during October, so it is unlikely that cell volume effects would be dampened or confounded due to adverse weather conditions.

In addition to these differences in location, 'Mission' tended to be influenced more often
Table 3. Effect of transplant container cell volume on early yield of 'Mission' and 'Superstar' muskmelon. ${ }^{\text {' }}$

\begin{tabular}{|c|c|c|c|c|c|c|c|}
\hline \multirow{3}{*}{$\begin{array}{l}\text { Cell vol } \\
\left(\mathrm{cm}^{3}\right)\end{array}$} & \multicolumn{4}{|c|}{ Early fruit no. (1000s/ha) } & \multicolumn{3}{|c|}{ Early fruit wt $\left(\mathrm{t} \cdot \mathrm{ha}^{-1}\right)^{\mathrm{y}}$} \\
\hline & \multicolumn{2}{|c|}{ Florida } & \multicolumn{2}{|c|}{ Indiana } & \multirow{2}{*}{\multicolumn{2}{|c|}{ Florida }} & Indiana \\
\hline & Mission & Superstar & Mission & Superstar & & Superstar & Mission Superstar \\
\hline
\end{tabular}

\begin{tabular}{|c|c|c|c|c|c|c|c|c|}
\hline \multicolumn{9}{|c|}{1993} \\
\hline 7 & 1.9 & 2.2 & $--^{x}$ & 0.0 & 2.2 & 4.2 & --- & 0.0 \\
\hline 22 & 5.7 & 3.4 & --- & 0.4 & 7.3 & 7.5 & --- & 1.5 \\
\hline 25 & 8.1 & 4.3 & --- & 1.3 & 9.4 & 8.8 & --- & 5.0 \\
\hline 36 & 6.6 & 3.6 & --- & 1.8 & 8.3 & 7.6 & --- & 7.2 \\
\hline 50 & 8.8 & 3.9 & --- & 3.2 & 11.1 & 7.1 & --- & 11.2 \\
\hline 70 & 11.2 & 4.3 & --- & 3.8 & 14.6 & 8.2 & --- & 15.8 \\
\hline 100 & --- & --- & --- & 3.6 & --- & --- & --- & 15.1 \\
\hline \multicolumn{9}{|l|}{ Significance } \\
\hline Cell volume & $\mathrm{L}^{* * * * *}$ & NS & --- & $\mathrm{L}^{* * * * *}$ & $\mathrm{~L}^{* * * * *}$ & NS & --- & $\mathrm{L}^{* * * * *}$ \\
\hline \multicolumn{9}{|c|}{1994} \\
\hline 7 & 3.3 & 5.1 & 3.7 & 1.5 & 3.7 & 10.4 & 6.5 & 4.0 \\
\hline 22 & 5.9 & 3.5 & 7.7 & 2.4 & 7.3 & 6.9 & 14.2 & 6.5 \\
\hline $25^{\mathrm{w}}$ & 11.1 & 4.2 & 3.2 & 2.8 & 13.9 & 8.5 & 6.6 & 8.3 \\
\hline 36 & 7.0 & 8.1 & 11.4 & 4.3 & 8.7 & 16.3 & 22.6 & 12.3 \\
\hline 50 & 16.5 & 6.2 & 6.9 & 1.9 & 18.0 & 12.8 & 13.5 & 6.1 \\
\hline 70 & 17.3 & 6.7 & 10.6 & 4.5 & 22.0 & 13.1 & 18.4 & 11.2 \\
\hline 100 & --- & --- & 10.6 & 4.3 & --- & --- & 19.7 & 13.8 \\
\hline
\end{tabular}

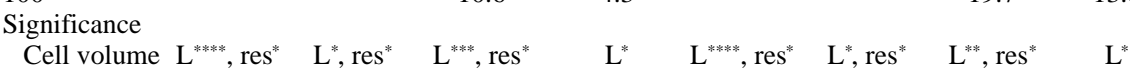

${ }^{2}$ Early yield defined as follows: Florida 1993, 'Mission' harvests 1 through 3 and 'Superstar' harvests 1 through 2; Indiana 1993, 'Superstar' harvests 1 through 4; Florida 1994, 'Mission' harvests 1 through 4 and 'Superstar' harvests 1 through 3; Indiana 1994, 'Mission' harvests 1 through 5 and 'Superstar' harvests 1 through 2.

yFlorida, 1994, data do not include weight of split melons.

${ }^{x}$ No data.

${ }^{\mathrm{w}}$ Cell volume was $26 \mathrm{~cm}^{3}$ in Indiana, 1994; otherwise $25 \mathrm{~cm}^{3}$.

Ns, ****,***,*****N Nonsignificant or significant at $P \leq 0.05,0.01,0.001$, or 0.0001 , respectively, for linear (L) or higher-order (res) effects of cell volume.

Table 4. Effect of transplant container cell volume on total yield of 'Mission' and 'Superstar' muskmelon.

\begin{tabular}{|c|c|c|c|c|c|c|c|c|}
\hline \multirow{3}{*}{$\begin{array}{l}\text { Cell vol } \\
\left(\mathrm{cm}^{3}\right) \\
\end{array}$} & \multicolumn{4}{|c|}{ Total fruit no. (1000s/ha) } & \multicolumn{4}{|c|}{ Total fruit wt $\left(\mathrm{t} \cdot \mathrm{ha}^{-1}\right)^{\mathrm{z}}$} \\
\hline & \multicolumn{2}{|c|}{ Florida } & \multicolumn{2}{|c|}{ Indiana } & \multicolumn{2}{|c|}{ Florida } & \multicolumn{2}{|c|}{ Indiana } \\
\hline & Mission & Superstar & Mission & Superstar & Mission & Superstar & Mission & Superstar \\
\hline \multicolumn{9}{|c|}{1993} \\
\hline 7 & 12 & 12 & 14 & 8.0 & 15 & 24 & 22 & 27 \\
\hline 22 & 20 & 13 & 14 & 10.0 & 26 & 27 & 24 & 34 \\
\hline 25 & 21 & 14 & 15 & 8.7 & 26 & 30 & 27 & 33 \\
\hline 36 & 22 & 14 & 17 & 10.0 & 27 & 30 & 29 & 39 \\
\hline 50 & 26 & 13 & 14 & 10.0 & 32 & 27 & 28 & 35 \\
\hline 70 & 26 & 14 & 14 & 9.1 & 33 & 29 & 26 & 36 \\
\hline 100 & $---y$ & --- & 18 & 9.7 & --- & --- & 31 & 39 \\
\hline Mean & 21 & 13 & 15 & 9.3 & 26 & 28 & 27 & 35 \\
\hline \multicolumn{9}{|l|}{$\begin{array}{l}\text { ANOVA } \\
\text { summary }^{\mathrm{x}}\end{array}$} \\
\hline Cultivar $(\mathrm{Cv})$ & \multicolumn{2}{|c|}{$* * * *$} & \multicolumn{2}{|c|}{$* * * *$} & \multicolumn{2}{|c|}{ NS } & \multicolumn{2}{|c|}{$* * * *$} \\
\hline Cell volume & \multicolumn{2}{|c|}{$\mathrm{L}^{* * *}$} & \multicolumn{2}{|c|}{ NS } & \multicolumn{2}{|c|}{$\mathrm{L}^{* *}$} & \multicolumn{2}{|c|}{$\mathrm{L}^{* *}$} \\
\hline $\mathrm{Cv} \times$ volume & \multicolumn{2}{|c|}{$\mathrm{L}^{* *}$} & \multicolumn{2}{|c|}{ NS } & \multicolumn{2}{|c|}{$\mathrm{L}^{*}$} & \multicolumn{2}{|c|}{ NS } \\
\hline \multicolumn{9}{|c|}{1994} \\
\hline 7 & 24 & 19 & 20 & 8.8 & 28 & 35 & 32 & 26 \\
\hline 22 & 27 & 17 & 18 & 9.0 & 34 & 30 & 31 & 24 \\
\hline $25^{\mathrm{w}}$ & 30 & 18 & 17 & 9.3 & 36 & 34 & 31 & 26 \\
\hline 36 & 26 & 21 & 19 & 8.8 & 34 & 39 & 34 & 25 \\
\hline 50 & 36 & 21 & 14 & 10.1 & 39 & 38 & 25 & 28 \\
\hline 70 & 37 & 23 & 14 & 10.6 & 47 & 45 & 23 & 28 \\
\hline 100 & --- & --- & 16 & 11.4 & --- & --- & 26 & 30 \\
\hline Mean & 30 & 20 & 17 & 9.7 & 37 & 37 & 29 & 27 \\
\hline \multicolumn{9}{|l|}{$\begin{array}{l}\text { ANOVA } \\
\text { summary }^{x}\end{array}$} \\
\hline $\mathrm{Cv}$ & \multicolumn{2}{|c|}{$* * * *$} & \multicolumn{2}{|c|}{$* * * *$} & \multicolumn{2}{|c|}{ NS } & \multicolumn{2}{|c|}{ NS } \\
\hline Cell volume & \multicolumn{2}{|c|}{$\mathrm{L}^{* * * * *}$} & \multirow{2}{*}{\multicolumn{2}{|c|}{$\begin{array}{l}\mathrm{NS} \\
\mathrm{L}^{* *}\end{array}$}} & \multirow{2}{*}{\multicolumn{2}{|c|}{$\mathrm{L}^{* * * * *}$}} & & NS \\
\hline $\mathrm{Cv} \times$ volume & $\mathrm{L}^{* *}$ & res $^{*}$ & & & & & & $L^{* *}$ \\
\hline
\end{tabular}

${ }^{2}$ Florida, 1994, data do not include weight of split melons.

${ }^{\text {y No data. }}$

${ }^{\mathrm{A}} \mathrm{ANOVA}=$ analysis of variance.

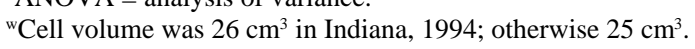

Ns, *************Nonsignificant or significant at $P \leq 0.05,0.01,0.001$, or 0.0001 , respectively, for main effect of cultivar and linear (L) or higher-order (res) effects of cell volume, or cultivar $\times$ cell volume. 
and more strongly by cell volume than 'Superstar' (Tables 3 and 4). Perhaps 'Mission' is more responsive because it produces more fruit per plant and, therefore, has greater potential for variation in yield. Also, the smaller root : shoot ratio of 'Mission' (Table 2) may make 'Mission' more responsive to conditions that limit its root development, such as decreased cell volume.

Size of fruit. The size of fruit was not influenced by cell volume in three of four trials (data not shown). In Indiana in 1993, fruit size increased linearly from 2.5 to $2.9 \mathrm{~kg} /$ fruit with increasing cell volume, but the effect was not large enough to be commercially significant 'Superstar' produced larger melons (mean 3.8 $\mathrm{kg}$ ) than 'Mission' (mean $2.3 \mathrm{~kg}$ ) in all trials.

These results lead to the general recommendation that growers considering a switch to smaller cell sizes should do so with caution: muskmelon transplants grown in the smaller containers may produce lower and later yields. For the cultivars and cell sizes that we used, more specific recommendations may be made. Florida growers who currently use $36-\mathrm{cm}^{3}$ cells for 'Mission' muskmelon could reduce cell volume to $25 \mathrm{~cm}^{3}$ without significant loss of early or total yield. Indiana growers may change from a $70-\mathrm{cm}^{3}$ cell to a $50-\mathrm{cm}^{3}$ cell with no effect on total yield, but early yield may be reduced. The economic benefits of more efficient use of greenhouse space must be weighed against the potential for lost income due to lower or delayed yields to determine whether moving to a smaller cell volume would be economically justified.

This paper has focused on the effects of cell volume, but the depth and shape of transplant container cells also may influence muskmelon growth and yield. In future studies, it would be useful to separate effects of volume and shape.

\section{Literature Cited}

Foster, R.E. (ed.). 1993. Midwest vegetable production guide for commercial vegetable growers. Purdue Univ. Ext. Bul. ID-56.

Hall, M.R. 1989. Cell size of seedling containers influences early vine growth and yield of transplanted watermelon. HortScience 24:771-773.

Hochmuth, G.J.(ed.). 1988. Muskmelon production guide for Florida. Fla. Coop. Ext. Circ. 122C.

Kemble, J.M., J.M. Davis, R.G. Gardner, and D.C. Sanders. 1994. Spacing, root cell volume, and age affect production and economics of com- pact-growth-habit tomatoes. HortScience 29:1460-1464.

Liptay, A. and D. Edwards. 1994. Tomato seedling growth in response to variation in root container shape. HortScience 29:633-635.

Marsh, D.B. and K.B. Paul. 1988. Influence of container type and cell size on cabbage transplant development and field performance. HortScience 23:310-311.

Vavrina, C.S., S. Olson, and J.A. Cornell. 1993. Watermelon transplant age: Influence on fruit yield. HortScience 28:789-790.

Waters, L.J., R.L. Burrows, M.A. Bennett, and J. Schoenecker. 1990. Seed moisture and transplant management techniques influence sweet corn stand establishment, growth, development, and yield. J. Amer. Soc. Hort. Sci. 115:888892.

Weimar, R. and H.G. Taber. 1987. Vegetable crop budgets. Iowa Coop. Ext. Bul. Pm 1185d.

Weston, L.A. 1988. Effect of flat cell size, transplant age, and production site on growth and yield of pepper transplants. HortScience 23:709-711.

Weston, L.A. and B.H. Zandstra. 1986. Effect of root container size and location of production on growth and yield of tomato transplants. J. Amer. Soc. Hort. Sci. 111:498-501.

Zimet, D. and C. Vavrina. 1995. Production of vegetable seedlings: Concept, budgets and cashflow. Florida Coop. Ext. Bul. 304. 